\title{
Handling Contraceptive Acceptors' Complaints by Using Android-Based Application
}

\author{
Nurhayani Jamil $^{1}$, Werna Nontji ${ }^{1,3}$, Syafruddin Syarif ${ }^{1,2}$, Mardiana Ahmad ${ }^{1}$, Suryani As ${ }^{`}$ ad $^{1,4}$, \\ Azniah Syam ${ }^{1,5} \&$ Andi Syarifah Irmadani ${ }^{1}$ \\ ${ }^{1}$ Postgraduate Program, Department of Midwifery, Hasanuddin University, Makassar, South Sulawesi, Indonesia \\ ${ }^{2}$ Department of Electrical Engineering, Hasanuddin University, Makassar, South Sulawesi, Indonesia \\ ${ }^{3}$ Diploma III of Midwifery Menara Primadani, Soppeng, South Sulawesi, Indonesia \\ ${ }^{4}$ Department of Clinical Nutrition at Hasanuddin University Teaching Hospital, South Sulawesi, Indonesia \\ ${ }^{5}$ SekolahTinggi Ilmu Kesehatan Nani Hasanuddin, Makassar, South Sulawesi, Indonesia \\ Correspondence: Nurhayani Jamil, Postgraduate Program, Department of Midwifery, Hasanuddin University, \\ Makassar, South Sulawesi 90245, Indonesia: Tel: 62-852-0305-2636. E-mail: jamil_nurhayani@yahoo.com
}

Received: May 30, 2019 Accepted: June 28, 2019 Online Published: July 9, 2019

doi:10.5539/gjhs.v11n9p61 URL: https://doi.org/10.5539/gjhs.v11n9p61

\begin{abstract}
Introduction: Contraception is a method which used to prevent pregnancy and to reduce the maternal mortality, particularly in $4 \mathrm{~T}$ condition; too young to give birth, too often to give birth, too close in spacing between births, and too old to give birth. However, the number of Drop Out from contraceptive in Indonesia is still high due to the concern of contraceptive acceptors about the side effects of contraception and the inaccuracy of re-injection schedule causing the acceptors to stop using contraception. Conventional method has been used by publics to manage the contraception for a long time. In this case, conventional method has been used to deal with the side effects of contraceptive use. By using the conventional method, the acceptor must visit the public health to consult their complaints to a midwife. Moreover, midwife will give the family planning control card to the acceptor which involves re-injection's schedule. However, many acceptors do not come to do re-injection as the schedule because they do not have an automatic reminder to remind them. Thus, the researcher interested to create a contraceptive's application in order to help the acceptors managing their schedule.
\end{abstract}

Material and Methods: This study employed comparative method to find out the comparison on the attitude of contraceptive acceptors in solving the problems by using the Smart Contraception application and conventional method. By using purposive sampling technique, 44 respondents were chosen in this study. The respondents were divided into two groups involving 22 respondents who used Smart Contraception application and 22 respondents who used conventional method. Then, the data were analyzed by using Chi-square test.

Results: The result of the study showed that the use of Smart Contraception application was better than conventional method in handling the problems experienced by contraceptive acceptors. The statistical result on the attitude of contraceptive acceptors in handling the problems of contraception shows p-value $0.026(<0.05)$ and p-value $0.023(<0.05)$ on the accuracy of re-injection schedule, which means that there was difference between the use of Smart Contraception application and conventional method.

Conclusion: There was difference between the use of Smart Contraception application and conventional method. Furthermore, the use of Smart Contraception was better than conventional method in handling the problems experienced by contraceptive acceptors.

Keywords: application, contraception, complaints' acceptor

\section{Introduction}

The family planning (KB) program has an essential role in creating a welfare and quality of health care for family in Indonesia. The contraception service aims to fulfill the needs of society in creating and implementing the quality family planning needs, to avoid unwanted pregnancy, thus it can make the society satisfy (Profil Kesehatan Republik Indonesia, 2015; Heike Theil de Bocanegra et al., 2016; Smith et al., 2013; Ajong Njotang et al., 2016; Rafidah, 2012). 
Contraception is a method which used to prevent a pregnancy and to reduce a maternal mortality. In Indonesia, most people use hormonal contraception. Contraceptive's side effect is the side effects caused by the use of contraception. Bleeding or spotting, changes in menstrual cycle, changes in body weight, headache, and nausea to vomit are the examples of 1-month injection's side effects. Early treatment for the acceptors by doing consultation about the side effects is needed. If the side effects cannot be treated properly, then it can make the contraceptive acceptor drop out. The contraceptive injection is one of the hormonal contraceptive methods and it is the most commonly used by Indonesian people at the percentage $60,91 \%$ or a half of all contraceptive methods which is used by Indonesian acceptors. Based on the data by Ministry of Health of Republic of Indonesia in 2013, a percentage frequency distribution of the contraceptive injection acceptors who experienced side effects after getting injection is $21,9 \%$. It is in line with Adriana Nur Aini (2016) who stated that $71,2 \%$ acceptors experienced side-effects of contraception and $86,5 \%$ of them felt disturbed. Therefore, the treatment of complaints by acceptors must be handled following the authority of midwifery (Kementerian Kesehatan RI, 2013; Rahayu, Budi Tri dkk, 2017.Departemen Kesehatan RI; 2018; Aini Nur Adriana, 2016).

The accuracy of re-injection schedule by the acceptor is the conformity of acceptor visit to do re-injection as the schedule provided by the midwife. The accuracy of re-injection schedule must be obediently followed by the acceptors since it is related with the use of contraception that suggested by midwives. The accuracy of re-injection schedule is an essential factor on the continuity of contraceptive use, but there are many acceptors who do not come according to their schedule due to forgetting the schedule of re-injection. It results ineffectiveness on the use of contraception and pregnancy. Sri Nilawati (2014) found that 18 (45.5\%) respondents did not come according to their re-injection schedule. Therefore, counseling is needed to help the acceptors get the contraceptive injection on time. There are several factors which cause the accuracy of re-injection schedule such as the acceptor's knowledge, occupation, husband's support, and health care facilities. Furthermore, a midwife also has an essential role in providing contraceptive consultation. She must provide midwifery care service standard which is stated in regulation of ministry of health of Republic of Indonesia Article 21 of 2017, the National Population and Family Planning Agency (BKKBN) Service Standard No. 163 / PER / D2 / 2011. Therefore, an innovation to deal with the side effect and inaccuracy of re-injection schedule experienced by contraceptive acceptors is needed (Mccarthy et al., 2017; Smith et al., 2013: Ajong Njotang et al., 2016 : Rafidah, 2012; Irianto Koes, 2014; Rafie et al., 2017; Kementerian Kesehatan, 2017; Rahayu, Budi Tri dkk, 2017; Aini Nur Adriana, 2016; Riyanti Eka, 2015; Nilawati Sri, 2014; Rumende Theresia, 2015; Notoatmojo, 2012; Sutrisno \& Ningsih, 2014; Valentino Nico, 2017).

The development of technology nowadays can be used to improve the quality of contraceptive services. One of the programs that can be used to improve the quality of contraceptive service is Technology Acceptance Mobile (TAM). TAM is easy, safety, beneficence program and fast in providing system (accessibility). Thus, the researcher interested to create a smart phone-based application to facilitate the acceptors in dealing with the side effects of contraception and the accuracy of re-injection schedule. The application is called Smart Contraception. It consists with three features such as consultation service provided by a midwife to acceptor, automatic reminder which will ring 3 days before the day to be injected, and contraceptive information which is needed by the acceptors (Koes Irianto, 2014; Yudhanto Yuda, 2018; Irsdyad Hanif, 2015; Permenkes, 2017; Oktariana, 2013; BKKBN, 2011; Yanti Elfrida, 2015, Abdul Bari Saifuddin, 2016; Kemenkes, 2016; Oktariana 2013; Harry et al., 2017; Bocanegra et al., 2017).

\section{Materials and Methods}

\subsection{Design of the Study and Sample Population}

The design of the study was quasi-experimental design by giving the treatment to the participants. This study was conducted at the public health center of Tamalate and Tamalanrea, Makassar starting from January to March 2019.By using purposive sampling technique, 44 respondents were chosen in this study. The respondents were divided into two groups involving 22 respondents who used Smart Contraception application and 22 respondents who used conventional method.

The researcher compared the use of android-based application and convention method. The researcher used android-based application, namely Smart Contraception, which was installed in every contraceptive acceptor in order to facilitate them in counseling and getting an automatic reminder of re-injection's schedule. Meanwhile, in conventional method groups, the researcher evaluated the way of midwives in giving consultation with the new contraceptive acceptors, and the accuracy of re-injection schedule using a Family Planning's (KB) card given by midwife.

The population of the study was all of the 1-month contraceptive acceptors who had complaints in using the contraception. By using purposive sampling technique, 22 respondents who used android-based contraception and 
22 respondents who used conventional method were chosen.

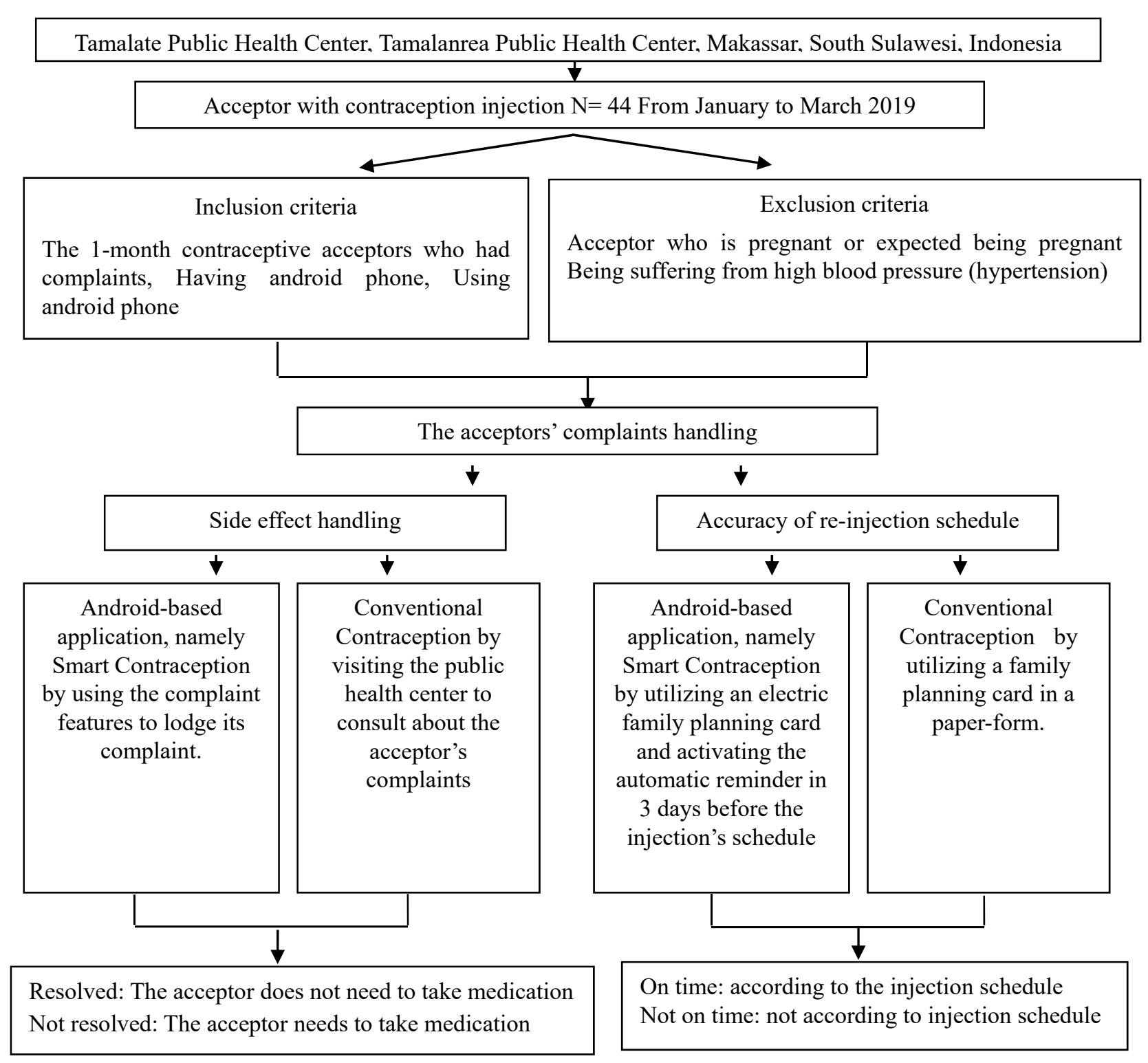

Figure 1. The flowchart of the study

\subsection{Data Collection}

The data were collected from January to March by monitoring the 1-month contraceptive injection acceptors who came to the health public center of Tamalate and Tamalanrea, Makassar, South Sulawesi. Moreover, they were given intervention by using Smart Contraception application or conventional method in order to evaluate the acceptors complaints handling and the accuracy of re-injection schedule.

\subsection{Ethical Considerations}

This study followed ethical clearance from the Research and Ethics Committee of Faculty of Medicine, Hasanuddin University and was registered in 1067/H4.8.4.5.31/PP36-KOMETIK/2018and protocol number UH18120961. 


\subsection{Data Management and Analysis}

Descriptive analysis was presented as a frequency. Chi-square test was used to assess differences in handling the complaints and the injection schedule which experienced by the acceptors.Data were analyzed using the Statistical Package for Social Science (SPSS) version 24 for Windows.

\section{Results}

The population of the study wasall of the 1-month contraceptive injection acceptors who had complaints in using the contraception. By using purposive sampling technique, 44 respondents; 22 respondents who used android-based contraception and 22 respondents who used conventional method were chosen.

\subsection{Univariate Analysis}

Univariate analysis was used to assess the characteristic of the respondents. The respondents were 44 acceptors; 22 respondents who used android-based contraception and 22 respondents who used conventional method.

Tabel 1. Characteristic of the respondents based on their age, the number of birth (parity), the educational background and the occupation

\begin{tabular}{|c|c|c|c|}
\hline \multirow{3}{*}{ Characteristics } & \multicolumn{3}{|c|}{ Handling Contraceptive Acceptors'Complaints } \\
\hline & Aplication & Conventional & \multirow[t]{2}{*}{$p$ Value } \\
\hline & $\mathrm{F} \quad \%$ & $\mathrm{~F} \quad \%$ & \\
\hline \multicolumn{4}{|l|}{ Age } \\
\hline$<20$ age & $2 \quad(9.1)$ & $(9.1)$ & 0,670 \\
\hline $20-30$ age & $19(86.4)$ & $20(90.9)$ & \\
\hline$>30$ age & $1 \quad(4.5)$ & & \\
\hline \multicolumn{4}{|l|}{ Parity } \\
\hline Nullipara & $16(72.7)$ & $14(63.6)$ & 1,000 \\
\hline Multipara & $6 \quad(27.3)$ & $8 \quad(36.4)$ & \\
\hline \multicolumn{4}{|c|}{ Educational Background } \\
\hline Tertiary education & $8 \quad(36.4)$ & $5 \quad(2.7)$ & 0,564 \\
\hline Secondary education & $11(50)$ & $15(68.2)$ & \\
\hline Primary education & $3 \quad(13.6)$ & $2 \quad(9.1)$ & \\
\hline \multicolumn{4}{|l|}{ Occupation } \\
\hline Housewives & $13(59.1)$ & $16(72.7)$ & 0,655 \\
\hline Working Women & $9 \quad(40.1)$ & $6 \quad(27.3)$ & \\
\hline
\end{tabular}

Source: Primary Data.

\subsection{Bivariate Analysis}

Bivariate analysis is used to differentiate the acceptors' attitude in handling the complaints or problems by using Smart Contraception application and conventional method. There were 44 respondents in this study; 22 respondents who used android-based contraception and 22 respondents who used conventional method were chosen. 
Table 2. The difference between the acceptors' attitude in handling the complaints or problems by using Smart Contraception application and conventional method

\begin{tabular}{llllll}
\hline \multirow{2}{*}{ Variable } & \multicolumn{4}{l}{ Side Effect Handling } \\
\cline { 2 - 6 } & \multicolumn{2}{l}{ Aplication } & \multicolumn{2}{l}{ Conventional } & \\
\cline { 2 - 6 } & $\mathrm{F}$ & $\%$ & $\mathrm{~F}$ & $\%$ \\
\hline Resolved & 20 & $(90.9)$ & 18 & $(81.8)$ & 0,026 \\
Not Resolved & 2 & $(9.1)$ & 4 & $(18.2)$ & \\
\hline
\end{tabular}

Source: Primary Data, Chi-Square Test.

Table 3. The difference between the accuracy of re-injection schedule of the acceptors by using Smart Contraception application and conventional method

\begin{tabular}{llllll}
\hline \multirow{2}{*}{ Variable } & \multicolumn{4}{l}{ Accuracy of re-injection schedule } \\
\cline { 2 - 6 } & \multicolumn{2}{l}{ Aplication } & \multicolumn{3}{l}{ Conventional } \\
\cline { 2 - 5 } & $\mathrm{F}$ & $\mathrm{F}$ & $\mathrm{F}$ Value \\
\hline On time & 19 & $(86.4)$ & 15 & $(68.2)$ & 0,023 \\
Not on time & 3 & $(13.6)$ & 7 & $(31.8)$ & \\
\hline
\end{tabular}

Source: Primary Data, Chi-Square Test.

\section{Discussion}

The data analysis of Chi-square shows that Smart Contraception application is better than conventional method in handling the contraceptive acceptors' complaints. This statement is proved by statistical result of p-value at 0.026 $(<0.05)$. Acceptor who use either conventional method or Smart Contraception application should counsult about their complaints as an early treatment given by midwife. It is based on the Health Service Standard BKKBN No. 163/PER/D2/2011 and Health Minister Regulation on Article 21 year 2017. Side effect occurred because a body's hormonal response toward the injection given. Estrogen hormones and progesterone in contraceptive injection gave a feedback to the pituitary gland through the hypothalamus which causes an obstacle to follicle development and ovulation. Thus, the release of Folicel Stimulating Hormone (FSH) can be hampered and it does not reach the maturity of Folicel De Graaf. Besides, progesterone also can inhibit the release of Luteinizing Hormon (LH). Meanwhile, Estrogen hormone accelerates tubal peristalsis in order to make the conception results reach the uterus in endometrial layer that is not ready to receive implantation. The advantage of estrogen hormone can cause nausea that sometimes followed by vomiting, head-aching, and weight gaining. Meanwhile, the advantage of progesterone can cause bleeding and menstrual cycle disruption. The side effects of contraception can affect to the discontinuation use of contraception by the acceptors. In this study, there were 44 respondents who had side-effects, 22 respondents who utilized Smart Contraception application and 22 respondents who utilized conventional method. There were 2 respondents who used the application but the complaints were not resolved since they needed further treatment such as medicine given by doctor. Meanwhile there are 4 respondents who used conventional method but their complaints could not be resolved since they need medicine treatment given by doctor. Overall, 3 respondents experienced spotting, 2 respondents experienced a change in body weight, 23 respondents experienced a headache, and 14 respondents experienced nausea to vomit. These side effects were informed to the midwife either by using an application method or conventional method (Aini Nur Adriana, 2016; BKKBN, 2016; Cunningham, 2017; Smith et al., 2013).

The results of the study were in line with Choi et al., (2019) who gave a diet consultation by using mobile system and conventional method. They found that statistical result of $p$ value at $0.001(<0.05)$ which means that there was difference in giving diet consultation by using mobile system and conventional method. The present study was also in line with Gillespie et al., (2017) who found that telemedicine help the midwives to observe the patients' condition at home as a way to minimize emergency visit and being hospitalized. Chris Smith et al., (2013) who studied about family planning services in the form of messages and voice calls found that there was an increase in service quality and acceptor satisfaction at a rate $44 \%$ by using MOTIF applications (Mobile Technology of Family Planning). Koes Irianto (2014) stated that handling acceptors problems or complaints is essential to prevent them drop out. The regulation of ministry of health regarding family planning service guidelines No. 21 of 2017 
concerns about the authority of midwives in providing the women's reproductive health service, family planning (KB) as counseling of reproduction, and oral contraceptive service, condom, and injection.

The data analysis of Chi-square also shows that Smart Contraception android-based application is better than conventional method in case of the accuracy of acceptors to visit the public health care. It was proved by the statistical analysis of $p$ value at $0,023(<0.05)$. Miller (1993) in Julianto Veri (1993) stated that human has a limited range of memories. Thus, the amount of information that can be received and processed is limited. Rehearsal technique is needed to get the repetition of information. This statement triggered the researcher to create an automatic reminder application 3 days before the re-injection schedule. However, in case of Smart Contraception application, it was found that 3 respondents did not come as the schedule. It was because they work, and although they have a free day, their free day did not suit with the re-injection's schedule. Meanwhile in conventional method, it was found that 7 respondents did not come as the schedule; 5 of them forgot the re-injection's schedule and 2 of them were working.

There were 19 out of 22 respondents of Smart Contraception application who visit public health care as the schedule due to their educational background which make them do it as midwife suggested. It was reported that 6 $(31.5 \%)$ repondents have a tertiary educational background meanwhile $10(52.6 \%)$ respondents have secondary educational background. In conventional method, there were 15 out of 22 respondents who visit publich health center as the schedule. $4(26.6 \%)$ respondents of these respondents have a have a tertiary educational background and $11(73.3 \%)$ respondents have secondary educational background. Their level education can cause their knowledge's level. The lower their educational level can cause the information or knowledge limited. Meanwhile the higher their level education, the way the understand the informationwill be increased (Notoatmodjo, 2012). Level of education the also effect to the way people creating idea and making new innovation (Pitriani Risa, 2015). The result of the study was supported by Bocanegra (2017) who used smsand e-mail as a reminder in a hand phone. The result of Bocanegra's study shows that 132 respondents $(81 \%)$ came on time with $p$ value at $0.001(<0.05)$. The result of the study was also in line with Triasminanto (2014) who create an application by using SMS model called Customer Relationship Manajemen (CRM). He succeeded in improving the contraceptive injection acceptor's obedience, namely Susiana Amini who lived in Pondok Sukoharjo village. The study indicates that there was a relationship between the use of family planning (KB)'s reminder by using sms and email in hand phone to the accuracy of injection schedule of acceptor. Moreover, there were some factors which influence the compliance of acceptors in doing contraceptive injection, such as their educational background and their background knowledge about the contraception (Rumende Theresia, 2015). The accuracy of injection acceptors is influenced by acceptors' adherence to the advice that given by health professionals (Muslima Ria, 2019). Miller (1993) in Julianto Veri (2017) stated that humans have limited capacity in their mind to remember, thus its limits to the particular amount of information which can be received, and processed. In order to recall it, the rehearsal technique is needed to receive the information. Thus, the researcher created an application as a reminder to facilitate the acceptors about their injection's schedule.

\section{Conclusion}

The use of Smart Contraception was better than conventional method in handling the problems or complaints of side effects and the accuracy of re-injection's schedule experienced by contraceptive acceptors.

\section{Acknowledgements}

The authors would like to express their special thanks to the Tamalate Public Health Center, Tamalanrea Public Health Center, Makassar City Health Office for their support and assistance.

\section{Competing Interests Statement}

The authors declare that there are no competing or potential conflicts of interest.

\section{References}

Agarwal, S., Lasway, C., Engle, K. L., Homan, R., Layer, E., Ollis, S., ... Mwakibete, A. (2016). Family Planning Counseling in Your Pocket: A Mobile Job Aid for Community Health Workers in Tanzania, 300-310. PMid:27353622. PMCid:PMC4982253. https://doi.org/10.9745/GHSP-D-15-00393

Ajong, A. B., Njotang, P. N., Kenfack, B., Yakum, M. N., \& Mbu, E. R. (2016). Knowledge of Women in Family Planning and Future Desire to Use Contraception: A cross Sectional Survey in Urban Cameroon. BMC Research Notes, 1-6. PMid:27431390 PMCid:PMC4949889. https://doi.org/10.1186/s13104-016-2155-7

Arikunto, S. (2013). Dasar-Dasar Evaluasi Pendidikan. Jakarta: BumiAksara.

Arum, D. N. S. (2011). Panduan Lengkap Pelayanan KB Terkini. Jogjakarta: NuhaMedika 
BKKBN. (2016). Pelayanan Kontrasepsi. Jakarta: BKKBN

Cunningham, A. F. (2017). Williams Obstetric. Jakarta; EGC

Dahlan, M. S. (2011). Statistik untuk kedokteran dan kesehatan. Penerbit Salemba.

Dahlan, M. S. (2014). Statistik untuk Kedokteran dan Kesehatan (6 ${ }^{\text {th }}$ ed.). Jakarta: Salemba Medika.

de Bocanegra, H. T., Bradsberry, M., Lewis, C., \& Maguire, F. (2017). Do Bedsider Family Planning Mobile Text Message and E-mail Reminders Increase Kept Appointments and Contraceptive Coverage?. Women's Health Issues, 27(4), 420-425. https://doi.org/10.1016/j.whi.2017.02.001

Faris, S. (2017). Pencarian Rumah Makan Berbasis Indikator. Jurnal Simetris, 8(1).

Hall, K. S., Westhoff, C. L., \& Castaño, P. M. (2013). The impact of an educational text message intervention on young urban women's knowledge of oral contraception. Contraception, 87(4), 449-454. https://doi.org/10.1016/j.contraception.2012.09.004

Halpern, V., Stalter, R. M., Owen, D. H., Dorflinger, L. J., Lendvay, A., \& Rademacher, K. H. (2015). Towards the development of a longer-acting injectable contraceptive: past research and current trends. Contraception, 92(1), 3-9. https://doi.org/10.1016/j.contraception.2015.02.014

Hancock, N. L., Vwalika, B., Sitali, E. S., Mbwili-Muleya, C., Chi, B. H., \& Stuart, G. S. (2015). Evaluation of service quality in family planning clinics in Lusaka, Zambia. Contraception, 92(4), 345-349. https://doi.org/10.1016/j.contraception.2015.06.025

Irianto, K. (2014). Pelayanan Keluarga Berencana. Bandung :Alfabeta

Irons, M., Tomaszewski, K., Buchanan, C. R. M., \& Trent, M. (2015). Understanding adolescent nonresponsiveness to text messages: lessons from the depotext trial. Journal of Urban Health, 92(3), 502-512. https://doi.org/10.1007/s11524-015-9950-7

Julianto, V. (2017). Meningkatkan memori jangka pendek dengan karawitan. Indigenous: Jurnal Ilmiah Psikologi, 2(2). https://doi.org/10.23917/indigenous.v2i2.5451

Kementerian Kesehatan RI. (2017). Profil Kesehatan Indonesia 2016. Jakarta: Kemenkes RI.

Maatilu, V., Mulyadi, N., \& Malara, R. (2014). Faktor-Faktor yang Berhubungan dengan Response Time Perawat pada Penanganan Pasien Gawat Darurat di IGD RSUP Prof. Dr. RD Kandou Manado. Jurnal Keperawatan, 2(2). https://doi.org/10.26630/jk.v8i3.668

McCarthy, O. L., Wazwaz, O., Jado, I., Leurent, B., Edwards, P., Adada, S., ... \& Free, C. (2017). An intervention delivered by text message to increase the acceptability of effective contraception among young women in Palestine: study protocol for a randomised controlled trial. Trials, 18(1), 454. https://doi.org/10.1186/s13063-017-2191-1

McCarthy, O., Leurent, B., Edwards, P., Tokhirov, R., \& Free, C. (2017). A randomised controlled trial of an intervention delivered by app instant messaging to increase the acceptability of effective contraception among young people in Tajikistan: study protocol. BMJ open, 7(9), e017606. https://doi.org/10.1136/bmjopen-2017-017606

Notoatmodjo, S. (2014). Ilmu Perilaku Kesehatan. Jakarta :RinekaCipta

Nyoman, S. I. (2013). Faktor-Faktor Yang Mempengaruhi Tingginya Laju Pertumbuhan dan Implementasi Kebijakan Penduduk di Provinsi Bali. PIRAMIDA, 12(1).

Rafie, S., Stone, R. H., Wilkinson, T. A., Borgelt, L. M., El-Ibiary, S. Y., \& Ragland, D. (2017). Role of the community pharmacist in emergency contraception counseling and delivery in the United States: current trends and future prospects. Integrated pharmacy research \& practice, $6,99$. https://doi.org/10.2147/IPRP.S99541

Reiss, K., Andersen, K., Barnard, S., Ngo, T. D., Biswas, K., Smith, C., ... \& Pearson, E. (2017). Using automated voice messages linked to telephone counselling to increase post-menstrual regulation contraceptive uptake and continuation in Bangladesh: study protocol for a randomised controlled trial. BMC public health, 17(1), 769. https://doi.org/10.1186/s12889-017-4703-z

Riyanti, E., \& Muhammadiyah, J. K. S. (2015). Gambaran pemakaian dan kepatuhan jadwal penyuntikan ulang kontrasepsi suntik. Jurnal Ilmiah Kesehatan Keperawatan, 11(1).

Rosa, A. S., \& Shalahuddin, M. (2013). Rekayasa perangkat lunak terstruktur dan berorientasi objek. Bandung: 
informatika.

Rumende, I. T. (2015). Evaluasi Penggunaan Kontrasepsi Suntik Pada Pasangan Usia Subur (Pus) Di Kelurahan Walian I Tomohon. PHARMACON, 4(1).

Saskara, I. D. (2015). Pengaruh Faktor Sosial, Ekonomi dan Demografi terhadap Penggunaan Kontrasepsi di Denpasar. Jurnal Ekonomi Kuantitatif Terapan, 8(2).

Scherwitzl, E. B., Danielsson, K. G., Sellberg, J. A., \& Scherwitzl, R. (2016). Fertility awareness-based mobile application for contraception. The European Journal of Contraception \& Reproductive Health Care. https://doi.org/10.3109/13625187.2016.1154143

Smith, C., Vannak, U., Sokhey, L., Ngo, T. D., Gold, J., Khut, K., ... \& Free, C. (2013). MObile Technology for Improved Family Planning services (MOTIF): study protocol for a randomised controlled trial. Trials, 14(1), 427. https://doi.org/10.1186/1745-6215-14-427

Sujarweni, V. W. (2014). Panduan Penelitian Kebidanan dengan SPSS. Pustaka Baru Pres: Yogyakarta.

Sutrisno, T. A., \& Ningsih, S. (2014). Pengembangan Model Customer Relationship Management Menggunakan Teknologi Sms Guna Meningkatkan Kepatuhan Akseptor KB. MEDIA ELEKTRIKA, 7(2).

Valentino, N. (2017). Gambaran Pengetahuan Ibu tentang Efek Samping KB Suntik 1 Bulan. Jurnal AKP, 8(1), 1.

Zuraidah. (2017). Pengaruh Pengetahuan Terhadap Persepsi Istri Dalam Penggunaan KB Non Hormonal. Midwife Journal, 3(1), 2017.

\section{Copyrights}

Copyright for this article is retained by the author(s), with first publication rights granted to the journal.

This is an open-access article distributed under the terms and conditions of the Creative Commons Attribution license (http://creativecommons.org/licenses/by/4.0/). 